\title{
Islam dan Politik dalam Era Orde Baru
}

\author{
Oleh : Afan Gaffar
}



Drs. Afan Gaffar, MA, Ph.D, adalah dosen tetap pada Jurusan IImu Pemerintahan Fakultas IImu Sosial dan IImu Politik Universitas Gadjah Mada Yogyakarta. Dilahirkan di Bima pada tanggal 21 Juni 1947. Afan Gaffar adalah lulusan IImu Pemerintahan Sospol UGM padatahun 1973. DerajatMaster(MA) dalam IImu.Politik diperoleh pada tahun 1979 dari Northen Illionis, sedangkan derajat doktor(Ph.D), juga dalam IImu Politik, diperoleh dari Ohio State University Amerika Serikat pada tahun 1988.

Banyak berbicara dan menulis dalam berbagai jurnal dan forum perjamuan ilmiah nasional maupun internasional dalam kapasitasnya sebagai "Political Sciencist". Selain bertugas sebagai pengelola dan pengajar Program Pasca Sarjana ISIPOL UGM Afan Gaffarmengajarjugadi berbagai PTS di Jawa, antara lain pada jurusan Tata Negara Fakultas Hukum UII-Yogyakarta.

"Saya tidakmaumasukICMI justru karena saya tak mau ikut berebut pangkat. Sebab disana sangat banyak orang yang begitu" (TEMPO, 10/11/1991)

\section{Pengantar}

Apa yang diungkapkan oleh Abdurakhman Wachid dalam kutipan di atas merupakan cerminan dari kondisi fragmentasi atau mungkin tepat dikatakan sebagai friksionalisasi dalam dunịa perpolitikan umat Isīam di Indonesia, yang menurut saya adalah cerminan dari kecenderungan ke arah fragmentasi yang sudah sejak lama ada. Kemungkinan kecenderungan tersebut akan berkelanjutan uuntuk masa-masa yang akan datang bukanlah sesuatu yang mustahil.
Membicarakan topik yang menyangkut Islam di Indonesia, apalagi dalam kaitannya dengan kedudukan dan proporsi politiknya, merupakan sesuatu yang selalu menarik, baik oleh kalangan Islam sendiri maupun di luar kalangan Islam. Cliford Geertz yang merupakan perintis dalam membahas topik ini membuka langkah awal dengan sejumlah studi anthroporolginya di Jawa, kemudian dilanjutkan oleh sejumlah ilmuan' sosial laininya.")

Khusus yang menyangkut màsalah Islam dan politik dalam masa pemerintahan

1) Harap periksa karya Geertz yang sangat monumental The Religion of Java (1960), juga The .Social History of Indonesian Town (1965), demikian juga Islam Observed (1968) 
Orde Baru sejumlah tulisan para ilmuwan asing banyak pula menaruh perhatian, seperti misalnya Alan Samson $(1968,1973)$ yang menyangkut konfigurasi dan fragmentasi politik Islam. Kemudian Ward (1973) menulis tentang Partai Muslimin, demikian juga Howard Fiederspeil (1973) yang membahas dengan menarik sekali tentang Muhammadyah; dan tentu saja Sidney Jones banyak sekali menaruh minat terhadap masalah Nahdlatul Ulama.

Kalangan pengamat asing kemudian tidak begitu lagi tertarik dengan masalah Islam dan Politik. Akan tetapi sejumlah ilmuwan Indonesia menaruh perhatian yang serius yang menyangkut topik ini, termasuk Fakhry Ali dan kawan-kawannya dari Ciputat seperti Bakhtiar Effendi, Din Syamsuddin yang banyak menaruh perhatian mengenal Islam dan Politik pada tahuan 1980an. Apa yang saya lakukan tentang "Politik Akomodasi" (1992) juga merupakan salah satu bentuk perhatian terhadap topik yang sama.

Apa yang dapat kita bicarakan tentang Islam dan Politik di Indonesia pada masa Orde Baru, tentama kita memasuki dekade tahun 1990an ini? Saya percaya masih banyak yang perlu diteliti oleh ilmuwan Indonesia yang mempunyai minat terhadap bidang ini, terutama dengan adanya suatu gejala pasca Pemilu 1992 di mana Islam menjadi suatu kekuatan politik yang harus diperhitungkan oleh banyak pihak sekalipun tidak disertai oleh adanya satu partai politik Islam seperti pada masa pasca kemerdekaan. Akan tetapi persoalan yang sangat mendasar, menurut hemat saya, yang menyangkut perpolitikan Islam masa Orde Baru ini adalah yang menỷangkut bagaimanakah Islam mengartikulasikan kepentingan politiknya yang tepat dalam . konteks kehidupan politik di Indonesia dengan meminimalisir risiko terjadinya konflik baik secara internal diantara sesama Islam, maupun dengan kekuatan politik lainnya, terutama yang berasal darikalangan sekuler, Kristen/Katolik, dan Angkatan Bersenjata.

\section{Permulaan Orde Baru : Kecurigaan dan Konflik}

Tidak ada seorangpun yang dapat menafikan bahwa umat Islam memainkan peranan yang sangat besar dalam menghancurkan kekuatan komunis di Indonesia dan sebagai salah satu komponen penegak Orde Baru yang sangat utama. Oleh karena itu pada permulaan lahimya Orde Baru harapan Umat Islam untuk melakukan kegiatan politik yang dilandasi oleh demokrasi tentu saja tinggi sekali.

Ketika sejumlah tokoh Islam (terutama tokoh partai Masyumi) dibebaskan dari penjaranya Sukamo pada tahun 1966 kerinduan dan optimisme akan munculnya satu partai politik Islam yang besar dan kuat tampaknya akan terwujud. Mantan Kétua Masyumi ketika dibubarkan pada tahun 1960, Prawoto mangkusasmito bahkan aktif sekali berusaha untuk mewujudkan rehabilitasi Masyumi sebagai Partai Politik. Akan tetapi usaha tersebut mendapat tantangan yang sangat keras dari berbagai pihak, terutama dari Angkatan - Darat, kalangan Kristen/Katolik, dan para tokoh Partai Nasional Indoneśia (Ward, 1970). Alasan yang banyak digunakan adalah Masyumi merupakan partai politik yang telah dibubarkan karena telah menyimpang dari PancasiladanUUD 1945 , dan banyak tokoh-tokohnya yang terlibat dalam peristiwa PRRI. Sekalipun secara formal alasan penolakan terhadap rehabilitasi Masyumi adalah karena 
persoalan "hukum dan psikologis", 2) kekhawatiran dari kalangan yang tidak senang dengan usaha rehabilitasi Masyumi sebenarnya karena mèreka melihat dengan dihadirkannya kembali Masyumi maka kekuatan politik Islam akan dengan mudah dimobilisasikan sehingga menjadi satu kekuatan politik yang sangat besar.

Hubungan yang mulai membaik antara Angkatan Darat dan Islam padamasa transisi menuju Orde Baru sedikit demi sedikit semakin melemah, bahkan di dalam perjalanan selanjutnya dilandasi oleh hubungan yang saling mencurigai dan tidak jarang diwarnai oleh konflik. Khusus usaha rehabilitasi Masyumi dan pembentukan pimpinan Partai Muslim Indonesia sebagai altematif dari Masyumi merupakan contoh yang sangat konkrit.

Ketika Partai Muslimin Indonesia (PMI) untuk pertama kalinya hendak mengadakan Muktamar di Malang pada tahun 1968, peserta Muktamar tampaknya sudah sepakat untuk memilih. Mr. Muhammad Rum sebagai Ketua Umum Partai yang banu tersebut. Akan tetapi pihak Angkatan darat keberatan dengan Mr. MuhammadRum karena beliau merupakan tokoh Masyumi yang masih sangat berpengarüh. ${ }^{3)} \mathrm{Hal}$ ini diperlihatkan oleh kebijaksanaan Presiden yang meminta Jenderal Alamsyah Ratuprawiranegara sebagai Sekretaris Negara mengirim telegram ke Malang untuk menginformasikan bahwa pemerintah tidakdapat menerima Muhammad Rum. Sebagai jalan keluar yang terbaik pada waktu itu adalah Kongres memilih Djamawi Hadikusumo dan Lukman Harun sebagai Ketua dan. Sekretaris Jenderal Partai Muslimin. Keduanya berasal dari Muhammadyah yang merupakan komponen yang terbesar dari partai tersebut.
Akan tetapi dalam waktu yang tidak lama kepemimpinan Djamawi-Lukman Harun tidak dapat bertahan dengan baik. Pihak pemerintah tampaknya kesulitan untuk menerimà kedua tokoh térsebut karena dianggap keras sekali dan tidak akomodatif. Atas rekayasa dari pihak opsus yang dipimpin oleh Ali Murtopo kepemimpinan partai tersebut diambil oleh Jaelani Naro dan Imran Kadir yang menimbulkan konflik internal dalam tubuh partai. Sehingga akibatnya pemerintah

2) Hal ini diperlihatkan oleh Surat dari Jenderal Suharto sebagai Ketua Presidium Kabinet, pada tanggal 6 January 1967 sebagai jawaban atas surat Prawoto Mangkusasmito tanggal 22 Desember 1966. Untuk lebih jelasnya harap diperhatikan Alam Pikiran dan Jejak Perjuangan Prawoto Mangkusasmito(1972, Surabaya, Dokumenta). Yang dimaksudkan dengan masalah "hukum" di sini adalah yang menyangkut interpretasi apakah pembubaran Masyumi itu sudah memenuhi ketentuan hukum, dan apakah Masyumi telah melanggar hukum. Kalangan pendukung dan tokoh Masyumi menyatakan bahwa apa yang dilakukan oleh Sukamo dalam membubarkan Masyumi adalah tidak syah menurut hukum, sementara orang menyatakan bahwa Masyumi sudah dibubarkan dan tidak dapat dihidupkan kembali karena melanggar hukum. Sementara itu secara "psikologis" mengandung makna bahwa Angkatan Darat dan kekuatan politik yang lainnya secara psikologis belum siap menerima kembali kehadiran Masyumi dan tokohnya dalam kehidupan politik di Indonesia.

3) Harap diperhatikan bahwa masalah diselenggarakan atau tidaknya Pemilihan Umum sudahmulaidengan santernya dibicarakan pada waktu itu, sehingga kepemimpinan partai politikIslamyang tangguh dianggap sebagai tantangan yang sangat kuat baik bagi Angkatan Darat, maupun partai politik yang lainnya." 
kemudian menunjuk MHS Mintareja sebagai Ketua Partài Muslimin.4)

Ketika menghadapi Pemilihan Umum 1971 konflik antara partai yang membawakan aspirasi Islam tersebut dengan pihak pemerintah berkelanjutan karena beberapa hal. Pertama,. yang berkaitan dengan kebijaksanaan Menteri Dalam Negeri No. 12 yang merupakan suatu usaha untuk melakukan pengebirian terhadap partai-partai politik di Indonesia. Kedua, Lembaga Pemilihan Umum yang diketuai oleh Mendagri memangkas dalam. jumlah yang sangat besar calon-calon yang diajukan oleh Partai Muslimin Indonesia, karena mereka merupakan mantan tokoh Masyumi yang sangat berpengaruh yang tentu saja akan sangat melemahkan partai pemerintah (Golkar) kalau mereka dibiarkan aktif dalam proses penyelenggaraan Pemilu (Afan Gaffar, 1988).

Hubungan yang tidak serasi antara Islam dan negara sejak permulaan Orde Baru dapat terjadi karena beberapa hal. Pertama, Islam secara prinsipal sangat percaya dengan prinsip demokrasi, dan kalangan Islam percaya bahwa dalam rangka mewujudkan kepentingan Islam yang lebih baij maka perjuangannya haruslah dilaksanakan secara demokratik dan didasarkan oleh prinsip-prinsip kehidupan politik yang demokratik. Kedua, umat Islam dihadapkan pada suatu kenyataan bahwa mayoritas penduduk di Indonesia ini adalah beragama Islam. Dengan - mekanisme penyelenggaraan. negara yang demokratik maka Umat Islam dengan mudah memobilisasikan dukungan sehingga pada akhimya menjadi suatu kekuatan politik yang sangat besar dan usaha untuk mewujudkan nilai-nilai Islam dalam segala aspek kehidupan politik lebih mudah dilaksanakan. Ketiga, di kalangan Islam sendiri terdapat individu yang - menginterprestasikan Islam secara harfiah/ ketat, sehingga di dalam mengartikulasikan kepentingan seringkali diperlihatkan dengan nada dan ekspresi yang keras, hitamputih baik di dalam mengeritik pemerintah maupun kelompok lain sehingga memicu konflik-konflik yang primordialistik.

Sementara itu persepsi pemerintah (khususnya Angkatan Darat) dan karakteristik pemerintahan Orde Baru juga memberikan kontribusi yang sangat besar terhadap ketidakseraian hubungan antara Islam dengan pemerintah. Kalangan Angkatan Darat karena pengalaman masa lampau yang sangat traumatik (DI/TII, Kahar Muzakkar, Daud Beureh) mempunyai persepsi yang kurang positif bahkan ada kecenderungan mencurigai pihak Islam. Kalangan Angkatan Bersenjata selalu mencurigai Islam sebagai kekuatan "Ekstrim Kanan", kelompok "Sempalan" yang selalu mengancam Pancasila dan persatuan dan kesatuan bangsa.

Yang tidak kalah pentingnya adalah yang berkaitan dengan karakteristik dari pemerintahan Orde Baru yang "authoritarian". Dalam rangka membentuk format politik yang baru, terutama dalam masamasa transisi dari Orde Baru pemerintah mengambil langkah yang dilakukān secara sistematik. Hal itu dilakukan melalui sejumlah kebijaksanaan, termasuk di dalamnya adalah (1) monoyalitas, (2) kebijaksanaan masa mengambang (floating mass), (3) emaskulasi dari partai-partai

4) Tepatnya pada tanggal 20 Nopember 1970. 
politik, ${ }^{5)}$ (4) pemilihan umum yang sama sekali tidak kompetitif, dan lain sebagainya. Kebijaksanaan tersebut menjadikan Islam sebagai target sasaran yang besar sekali yang memancing reaksi Islam.

Di samping itu pemerintah menempuh kebijaksanaan yang secara spesifik mengundang konflik yang tak terhindarkan dengan Islam. Dalam hal ini dapat disebutkan dimulai dengan (1) Undang-undang Perkawinan, (2) masalah. perjudian di Jakarta, (3) diberlakukannya kebathinan setingkat dengan agama yang disyahkan melalui Sidang Umum MPR tahun 1988, (4) dihapuskannya liburan semasa bulan Ramadhan, (5) pelarangan memakai busana Muslim/berjilbab bagi siswi Sekolah Menengah di beberapa daerah, masalah SDSB. Issue-issue tersebut mempunyai tingkat sensitifitas yang tinggi sehingga dengan sangat gampang memicu konflik karena seringkali dikaitkan dengan masalah akidah Islam, sehingga dapat merugikan kepentingan Islam di Indonesia.

\section{Akhir 1980-an : Saling Akomodasi क}

Memasuki periode terakhir dekade 1980an tampaknya pemerintah secara perlahan-lahan mengambil kebijaksanaan yang akomodatif terhadap Islam di Indonesia. Hal ini. dapat kita lihat dari sejumlah indikator berikut ini.

1.Sejak kementerian Pendidikan dan Kebudayaan di percayakan kepada Menteri Fuad Hasan, sejumlah kebijaksanaan yang selama ini dianggap sangat merugikan Islam mulai ditinggalkan, seperti misalnya dihapuskannya larangan berbusana muslim bagi sejumlah siswa sekolah:lanjutan. Pada. masa Departemen Pendidikan dan Kebudayaan yang dipegang oleh Daud Yusuf umat Islam menganggap bahwa. kebijaksanaan Daud Yusuf (larangan berbusana muslim, dicabutnyaliburan bulan puasa) yang dianggap merugikan gaya kepemimpinan Daud Yusuf yang sering diterima sebagai menantang Islam. Hal ini bebeda sekali dengan gaya dan kebijaksanaan menteri pendidikan Fuad Hasan.

2. Ketika Rancangan UndangUndang Sistem Pendidikan Nasional dibicarakan di DPR, sejumlah pemuka agama Islam mengingatkan bahwa RUU tersebut tidak memberikan tempat yang sebenarnya bagi pendidikan agama. Sejumlah organisasi massa Islam berhasil melakukan diskusi dan "lobbying" yang serius sehingga ketika RUU tersebut ditetapkanmenjadi Undang-Undang Sistem Pendidikan Nasional pada tahun. 1989 beberapa pasal yang menyangkut peranan pendidikan agama sudah dimasukan, bahkanpada hari terakhir partai PPP berhasil melakukan amendemen di dalam penjelasannya bahwa "antara pengajar dan anak didik harus memiliki agama yang sama", yang tentu saja tidak disenangi oleh Kalàngan Kristen/Katolik.

5) Salah satu cara dalam melakuka emaskulasi terhadap partai politik adalah dengan mengontrol pola rekruitmen dalam lingkungan partai tersebut. Salah satu syarat yang tidak tertulis dari pola rekritmen tersebut adalah "derajat akomodatif" nya dengan pemerintah. Hal itu terlihat baik di dalam Partai Muslimin Indonesia (Mendukung Mintareja dan Naro, Cs), kemudian Partai Nasional Indonesia (memilih Hadisubeno dari pada Hardi) yang diteruskan dalam Partai Demokrasi Indonesia.

6) Para kaum sinis tidak sependapat dengan istilah politik akomodasi, ada yang lebih cenderung melihat pola hubungan tersebut dalam bentuk satu arah di mana Islam digunakan oleh permerintah (baca: Presiden)' untuk memobilisasikan dukungan. Jadi Islam lebih banyak dimanfaatkan kata sementara orang. 
3. Tidak ada masalah persurat kabaran yang sangatmenarik perhatian dari pada Mingguan Monitor. Mingguan yang dibuatoleh Katolik tersebut memuat tulisan yang dianggap menghina Islam di Indonesia sehingga dengan cepat memicu kemarahan umat Islam. Pemerintah kemudian dengan secepatnya membredel koran tersebut, dan bahkan pemimpin redaksinya kemudian diadili dan telah mendapat hukuman lima tahun penjara.

4. Salah satu RUU yang cukup mendapat tantangan dari kalangan nonIslam adalah RUU Peradilan Agama. Kalangan non-Islam berpendapat bahwa dengan diajukannya RUU tersebut berarti hendak memperlakukan kembali "Piagam Jakarta". Mereka berhasil membentuk pendapat umum melalui media massa yang sangat berpengaruh, yaitu KOMPAS dan SUARA PEMBAHARUAN, dan Fraksi Karya pada awalnya sudah mendukung kelompoknon-Islam. ${ }^{D}$ Akan tetapi setelah Presiden Suharto sendiri memberikan jaminan bahwa pemerintah tidak akan memberlakukan Piagam Jakarta baru pembahasanRUU tersebut berjalan dengan baik, dan menjadi UU Peradilan Agama Islam.

\section{Ketika Menteri Agama Munawwir Sadzali menutup Muktamar} Muhammadyah di Yogyakarta pada tahun 1989 dihadapan peserta Muktamar beliau mengumumkan bahwa Presiden Suharto melalui Yayasan Amal Bakti Muslim Pancasila akan mengirim 1000 da'i ke daerah-daerah transmigrasi dengan diberi jaminan hidup sebanyak Rp. 100.000 setiap bulannya dan diberi sepeda sebagai alat transport.

6. Dan tentu saja yang sangat penting bahkan paling menarik untuk dibicarakan adakan phenomena kelahiran Ikatan
Cendekiawan Muslim Indonesia (ICMI). Ketika Organisasi ini dibentuk di Malang, Presiden Suharto sendiri hadir bersama sejumlah pejabat tinggi negara. Hal ini menandakan bahwa pemerintah memberikan dukungan yang kuat bagi kehadiran ICMI. Bagaimana struktur organisasinya, bagaimana ikatannya dengan birokrasi, bagaimana ICMI berperan dalam membina hubungan antar Islam dengan pemerintah memperlihatkan dengan jelas kecenderunganke arah akomodasi tersebut.

7. Yang tidak kalah menarik adalah adanya komitmen Presiden Suharto untuk membantu umat Islam untuk membuat dan memperbaiki sarana peribadatan, melalui Yayasan Amal Bakti Muslim Pancasila. Melalui yayasan ini ratusan masjid sudah dibangun yang tersebar di hampir segala pelosok tanah air.

8. Dalam rangka rekruitmen politik untuk mengisi keanggotaan MPR sejumlah intelektual yang dikenal mempunyai latar belakang keislaman yang kuat diangkat menjadi anggota MPR mewakili "golongan," bahkan individu yang sebelumnya dikenal sebagai salah seorang pengeritik pemerintah yang keras sekali menjadi anggota MPR.

Barangkali masih banyak sekali indikator yang dapat digunakan untuk memperlihatkan gejala akomodatifnya pemerintah terhadap Isalam. Bagaimana dengan Islam sendiri? Gejala akomodasi dari kalangan Islam dapat dilihat dari pelbagai indikator perilaku politik yang. sudah sangat umum dikenal masyarakat secara luas, yaitu:

7) Frans Magnis Suseno secara aktif menulis di Kompas dan mengeritik RUU tersebut, demikian juga dengan Mulya Lubis yang mènulis di Harian yang sama. 
1. Adalah sejumlah tokoh Islam yang pertama kali memperlihatkan dukungan untuk memilih kembali Presiden Suharto untuk masa jabatan periode 1993-1998. Sejumlah ulama memberikan ikrar dukungannya. Hal ini berbeda sekali dengan organisasi mass lainnya yang mungkin menghendaki adanya pola rekruitmen politik yang lain dari masa-masa sebelumnya.

2. Pada sekitar bulan Juni 1992 salah satu organisasi masa Islam yang terbesar, Muhammadyah, datang menemui Presiden Suharto. Ketika ditanya oleh wartawan Pimpinan Muhammadyah menyatakan mendukung terpilihnya kembali Presiden Suharto untuk masa jabatan periode 1993 1998. Apa yang dilakukan oleh Muhammdyah kemudian diikuti oleh sejumlah organisasi massa lainnya, termasuk Persatuan Sarikat Islam. Indonesia.

3. Puncak dari gerakan dukungan yang dilakukan oleh orang Islam kepada Presiden Suharto adalah dengan diadakannya do'a politik untuk kesehatan Presiden dan agarsupaya pemilihan kembali Presiden Suharto berjalan dengan lancar.

Pertanyaan yang muncul kemudian adalah mengapa saling akomodasi politik terjadi? Ada beberapa kemungkinan jawaban yang dapat diajukan, yaitu pertama pemerintah sudah menganggap bahwa Islam di Indonesia bukan lagi sebagai kekuatan yang dapat mengancam stabilitas politik nasional. Atau kemungkinan yang kedua adalah bahwa pemerintah melakukan akomodasi politik terhadap Islam dalam rangka usaha untuk mencari dukungan terhadap Islam; atau kemungkinan yang lainnya adalah dengan akomodasi politik maka akan mudah mengatur politik Islam di Indonesia. Sementara itu, dari kalangan
Islam politik akomodasi perlu ditempuh agar supaya pertama memiliki akses yang cukup dalam proses pengambilan kebijaksanaan, jadi daripada șelama ini menjadi pemain pinggiran maka sudah waktunya untuk bermain akses yang kuat dalam pengambilan keputusan. Kedua, akomodasi dilakukan sebagai imbalan atas kebijaksanaan pemerintah yang sudah mulai memperhatikan Islam untuk masa-masa yang akan datang, dan bahkan Islam akan memperoleh imbalan yang lebih besar lagi dalam skala politik nasional.

Masyarakat Islam di Indonesia merasakan adanya perubahan yang cukup besar perlakuan pemerintah atas Islam. Betapa Islam menyambut dengan gembira ketika Presiden dan keluarga dan sejumlah pejabat tinggi negara menjalankan ibadah hajji pada tahun 1991 dan kemudian memperoleh tambahan nama "Muhammad" dari Raja Fahd. Setiap pemyataan dukungan terhadap Presiden yang berasal dari kalangan Islam "attribut" yang berwujud "Haji Muhammad" selalu diungkapkan dengan penuh kebanggan.

\section{Kepemimpinan Islam Produk Orde Baru}

Salah satu kenyataan yang tidak dapat dipungkiri adalah Orde Baru membawa berkah yang sangat besar bagi Islam di Indonesia kalau ditinjau dari kesempatan untuk memperoleh pendidikan yang lebih baik. Kalau pada masa pemerintahan kolonial yang paling besar peluang untuk memperoleh pendidikan yang lebih baik adalah anak keturunan dari kalangan bangsawan, kalangan priyayi, dan mereka yang beragama kristen dan katolik yang memperoleh dukungan yang dari gereja. Kalangan Islam hanyalah mempunyai kesempatan yang terbatas dengan 
menikmati pendidikan tradisional di pesantren dan lembaga pendidikan Islam lainnya, atau kalau mereka yang berasal dari kalangan priyayi memperoleh peluang yang lumayan.

Oleh karena itu kelompok masyarakat yang sangat banyak dikenal sebagai kelompok yang memiliki intelektualitas yang tinggi hanyalah mereka yang berasal dari kalangan priyayi dan kalangan nasrani. Pada masa pasca kemerdekaan kalangan ilmuwan barat banyak sekali mengadakan kontak dengan kalangan intelektual tersebut dan mereka merupakan sumber informasi yang paling utama di dalam membahas atau meneliti Indonesia. ${ }^{8)}$ George Kahin dalam bukunya "Nationalism and Revolution in Indonesia" banyak sekali membicarakan Syahrir, demikian juga dengan Herbert Feith di dalam The Decline of Constitutional Democracy yang sangat mempromosikan Syahrir. Kontak mereka dengan Indonesia banyak sekali mereka yang merupakan pengikut Syahrir di Jakarta. Sehingga menimbulkan kesan bahwa monopoli intelektualitas hanyalah dimiliki oleh kalangan pengikut Syahrir dan kalangan gereja. Mungkin hal ini disebabkan oleh keunggulan mereka dalam menguasai bahasa asing.")

Dengan adanya Orde Baru sejumlah generasi muda muslim memperoleh kenikmatan untuk mengenyam pendidikan tinggi di dalam negeri pada perguruan tinggi yang sangat menonjol, demikian pula di luar negeri. Sejumlah nama dapat kita sebutkan, seperti misalnya Amin Rais. Ahmad Syafii Ma'arif, Kuntowidjojo, Yahya Muhaimin, Ahmad Watik Pratignya, Umar Anggoro Jeni, Jamaluddin Ancok, Sofian Effendi di Yogyakarta. Sementara itu di Jakarta masyarakat mengenal intelektual muslim seperti Abdurakhman Wakhid, Nurcholis Madjid, Joham Effendi, Amin Aziz, Dawam Rahardjo, Adi Sasono, Sri Bintang Pamungkas, Aswab Mahasin, dan masih banyak lagi. Di Bogor A.M. Saefuddin mempelopori kemunculan intelektual muslim, demikian juga dengan sejumlah mereka yang berada di Bandung (Salman dan Mizan), Surabaya (Group Al Fallah), Malang, Semarang, dan kota besar lainnya di luar Jawa.

Akan tetapi temyata masyarakat Islam di Indonesia juga mengalami perkembangan yang sangat menarik. Di daerah perkotaan mereka memperlukan siraman pemikiran keagamaan yang merupakan campuran dari nilai-nilai agama dan interprestasi terhadap kehidupan yang modem. Dari pengalaman di Yogyakarta dan Bandungmereka sangat aktif memenuhi panggilan masyarakat untuk menjelaskan modem di satu pihak dan ajaran Al Qur'an pada pihak yang lainnya.

Di samping itu yang paling menarik untuk dicatat adalah mereka ternyata mampu mengisi kepemimpinan Islam yang

8) Kalau kita membaca buku yang terbit dari tahun 1960an dan tahun 1970, sebagian terbesar kontak mereka adalah dengan kalangan yang secara idiologis dikenal sebagai orang-orang yang sosialis, dan orang kristen katolik. Ucapan terima kasih dalam buku tersebut dapat kita gunakan sebagai indikator.

9) Kecenderungan dari kalangan pengamat barat untuk melecehkan Islam juga masih berkelanjutan. Kalau kita mengamati Pertemuan. Monash untuk menghantarkan pensiunnya Herbert Feith, sebagian besar pengikut Syahrir/Sudjatmoko dan gereja, sedangkan Islam tidak mendapat porsi yangsewajarnya. Adalah sesuatuyang ironis, menurut hemat saya, membicarakan masalah prospek demokrasi di Indonesia dengan tidak memperhitungkan Islam secara proporsional karena bagaimanapun juga Islam harud diperhitungkan karena termasuk sesuatu yang dipertahankan. 
baru di Indonesia menggantikan mereka yangmerupakan generasi sebelumnya yang mempunyai persepsi yang berbeda dengan generasi baru yang berkaitan dengan Islam dan Politik dalam konteks kehidupan politik di Indonesia. Yang menjadi penggerak utama kepemimpinan dalam Muhammadyah yang sekarang adalah orang-orang seperti Amin Rais, Syafii Ma'arif, Watik Pratignya, Yahya Muhaimin dan yang lain-lainnya. Sementara itu di Nahdlatul Ulama Abdurrakhman Wachid merupakan komponen yang paling utama yang mempunyai kharisma tersendiri di kalangan umat Islam di Indonesia.

Dengan demikian kita dapat menyaksikan bahwa kepemimpinan Islam yang baru mempunyai karakteristik yang jauh berbeda dengan kepemimpinan pasca kemerdekaan, yaitu pertama mereka mempunyai latarbelakang pendidikan yang tidak lagi' di dominasi oleh pendidikan tradisional Islam di Jawa (pesantren), pendidikan mereka adalah campuran antara ilmu pengetahuan umum/sekuler dengan ilmu pengetahuan keagamaan. Hal ini berbedasekali dengan kepemimpinan Islam pada masa pasca kemerdekaan. Kedua, mereka juga banyak yang berkecimpung dalam dunia akademik sebagai tenaga pengajar di perguruan tinggi ataupun sebagai peneliti di departemennya masingmasing maupun di lembaga swasta. Kita dapat mengungkapkan nama mereka satu persatu yang berasal dari berbagai kota besar di mana terdapat perguruan tinggi yang secara nasional diakui kepeloporannya. Ketiga, kebanyakan mereka tidaklahmenjadi politisi profesional dengan menjadi tokoh dari partai politik sehingga tidak memilih jalan berparlemen sebagai salah satu cara untuk berartikulasi kepentingan agama Islam di Indonesia.
Apakah kemudian yang menjadi implikasi dari kepemimpinan Islam seperti ini? Menurut hemat saya terjadi pergeseran yang fundamental yang menyangkut pertamapersepsi tentang tujuan perpolitikan Islam dan yang kedua modus dalam berpolitik.

Yang menyangkut tujuan perpolitikan Islam dapat dikatakan bahwa apa yang hendak diperjuangkan tidak lagi seperti generasi kepemimpinan pasca kemerdekaan yaitu terwujudnya Islam sebagai dasar negara, akan tetapi "bagaimana Islam memperoleh representasi yang wajar dan proporsional sesuai dengan besarnya potensi umat Islam. Artinya, bagaimana Islam supaya selalu diperhitungkan dalam perpolitikan nasional dan bagaimana Islam mempunyai akses yang besar dalam pengambilan kebijaksanaan. Dengan demikian nilai-nilai Islam akan mewarnai kehidupan berbangsa dan bermegara di tanah air". Untuk mencapai tujuan tersebut mereka sama sekali tidak akan mengorbankan kepentingan negara kesatuan karena mereka merupakan nasionalis yang juga cinta kepada keutuhan dan kesatuannegara Indonesia dari Sabang sampai Merauke. Mereka mempunyai toleransi yang tinggi terhadap eksistensi kelompok dan agama lain karena hal itu sudah sepantasnya seperti yang diajarkan dalam Âl Qur'an.

Dari pengalaman perpolitikan sejak permulaan Orde Baru mereka pada umumnya menyadari bahwa hakekatpolitik di Indonesia adalah suatu pertaruhan yang dapat membawa manfaat yang maksimal atau dapat membawa kerugian yang sangat besar, bahkan bisa kehilangan segalagalanya.PolitikIndonesia Orde Baru adalah politik yang diwamai oleh zero-sum game, suatu pertaruhan yang dapatmenghabiskan 
segala-galanya kalau kalah. Oleh karena itu melawan pemerintah Orde Baru atau menempatkan diri sebagai kelompok oposisi adalah suatu yang sangat sulit untuk dilakukan karena pemerintah Orde Baru sudah sedemikian kuatnya sehingga tidak mungkin lagi untuk dihadapi dengan modus perpolitikan pasca kemerdekaan. Kalau pada masa permulaan Orde Banu sampau dengan awal tahun 1980an Islam menempatkan diri dalam posisi pinggiran, maka kecenderungan terakhir dapat kita amati adalah bagaimana Islám punya akses dalam proses pengambilan keputusan nasional, sehingga Islam menjadi responsif terhadap segala persoalan negara dengan cepat. Dengan demikian kepemimpinan Islam yang 'sekarang ini menjadi realistis dan pragmatis dengan tanpa meninggalkan prinsip dan tujụan perjuangan Islam.

Adalah hal yang sangat wajar kalau sekarang kita mengamati bahwa semakin banyaknya komponen kepemimpinan Islam yangmemperlihatkansikapyang cenderung mendukung pemerintah, banyak yang aktif dalam organisasi yang mempunyai kaitannya dengan pemerintah sehingga tidaklah mengherankan kalau mereka misalnya menjadi anggota fraksi partai pemerintah dalam lembaga perwakilan rakyat.

\section{Penutup : Mencari Modus Artikulasi}

Sekalipun politik Islam Orde Barusudạh mengalami perubahan yang sangat fundamental, akan tetapi persoalan bagaimana mencari bentuk artikulasi kepentingan Islam yang tepat dalam rangka meningkatkan tujuan perpolitikan Islam (dalam hal ini bagaimana representasi Islam secara wajar dan proporsional sesuai dengan potensi Islam) sehingga tidak menimbulkan reaksi yang negatif baik dari kalangan internal Islam sendiri maupun yang berasal dari kalangan non-Islam sehingga dapat merugikan kepentingan politik Islam pada akhimya.

Kașus ICMI kiranya dapat kita jadikan bahan kajian. Kehadiran ICMI dalam masyarakat ternyata berhasil membangunkan Islam dalam rangka mencari modus untuk mempersatukan potensi intelektualitas ummat. Akan tetapi di dalam cara berskpressinya tidak jarang ICMI seperti "Burung Merak" yang mengepakkan sayapnya dan gagah bulunya akan tetapi mempunyai kesan "menantang" lingkungan di sekitamya, hal itu tentu saja menimbulkan reaksi yang kurang positif.

Sekalipun dari kalangan Islam hanyalah Abdurakman Wachid yang menyatakan secara terbuka untuk tidak bergabung dengan ICMI karena ingin menangani hal lain, akan tetapi karena Abdurakhman Wachid mempunyai jalur hubungan dengan kalangan non-islam yang baik sekali sehingga kecamannya bahwa ICMI merupakan langkah mundur yang menuju ke arah sektarianisme politik Indonesia mendapat porsi yang sangat besar di media massa (Kompas, Suara Pembaharuan, Jawa Pos, TEMPO, Editor, DIl) yang bagaimanapun juga merupakan representasi dari kepentingan mereka masing-masing.

Persoalan pembinaan hubungan antara sesama komponen kepemimpinan Islam tampaknya masih merupakan persoalan yang kronis sekali yang menimbulkan friksi yang cukup tajam, yang sebenamya merupakan warisan sejarah. Hal ini dapat kita lihat antara Muhammadyah dengan NU, sebagai dua organisasi massa Islam terbesar di Tanah Air. Ketika Kiyahi Sidih sebagai Rois Aam Nahdlatul Ulama 
hubungan antara NU " dengan Muhammadiyah terlihatnya sangat serasi, terjadi komunikasi yang sangat teratur dan baik antara pak A.R. Farkhruddin dengan Kiyahi Sidik. Tampaknya kompatibilitas kepemimpinan diantara keduabeliau sangat cocok. Akan tetapi hal itu sudah tidak lagi kita temukan sekarangini,sekalipun kontak - individual masih tetap berjalan, misalnya antara orang-orang Muhammadyah dengan Kiyahi Yusuf Hasyim dan lain-lainnya.

Kehadiran ICMI juga telah mengakibatkan kalangan Islam dan "sekuler" memasang kuda-kuda. Mereka mempunyai kekhawatiran bahwa kehadiran ICMI dan cara beratikulasinya telah mengembalikan perpolitikan Indonesia kembali ke pada masa pasca kemerdekaan. Bahkan tidak jarang muncul suara-suara yang melecehkan seperti misalnya ICMI sebagai sarana untuk mencari pangkat dan jabatan. ${ }^{11)}$

Ketika sejumlah cendekiawan Muslim mewarnai proses reknuitmen anggota MPR tahun 1992 yang baru lalu, orang kemudian dengan serta merta menggambarkan sebagai proses penghijauan dari lembaga tersebut. Reaksi yang paling menonjol adalah muncul dari kalangan Kristen dengan mengadakan pertemuan di Wisma Kinasih dalam dengan alasan menyambut Sidang Umum MPR.

Menurut hemat saya reaksi-reaksi tersebut merupakan resonansi dari bagaimana cara Islam mengekspresikan kepentingan politiknya yang kemudian menimbulkan rasa kekhawatiran dari kalangan Islam itu sendiri dan lebih lagi kalangan kalangan non-islam. Oleh karena itu salah satu persoalan yang dihadapi oleh politik Islam Orde Baru adalah menyangkut "mode of articulation" 'yang efisien dan effektif sehingga orang lain tidak curiga dan khawatir yang pada akhimya juga mampú membentuk opini masyarakat yang merugikan kepentingan Islam.

Bagaimana caranya ? Hal itu memerlukan waktu untuk memikirkannya. Saya sendiri pada saat sekarang ini kurang tahu akan hal itu, tugas kita semua terutama mereka yang menjadi politisidan pemimpin umat untuk memikirkannya, agar bagaimana Islam mendapat tempat yang proporsional dan politik Indonesia sesuai dengan potensi umat. Saya mengharapkan agarmodel penampilan cara burung Merak, baik secara sadar ataupun tidak supaya perlu dipikirkan kembali, sehingga apa yang disebut dengan penampilan yaing low profile seperti yang dilakukan oleh kalangan non-islam merupakan altematif yang sangat efisien dan effektif.

Akan tetapi satu hal yang perlu mendapat perhatian kita semua adalah komunikasi yang intensif baik yang dilakukan secara internal, dalam arti antara sesama organisasi massa Islam, maupun secara ekstemal terutama dengan kalangan non-islam dan angkatan bersenjata. Mengapa yang terakhir ini penting ? Tentu saja mengingat posisi strategis ABRI sebagai kekuatan politik yang harus selalu dipertimbangkan, karena kalau sampai terjadi salah pengertian dengan ABRI maka akan menimbulkan masalah yang berkepanjangan seperti pengalamanpengalaman masa lampau, itulah realitas politik pada masa lampau.

11) Dari kalangan mereka yang sinis ICMI diekspresikan sebagai Ikatan Calo Menteri Indonesia, Ikatan Cendekiawan Mualaf Indonesia karena dianggap bahwa gejala meningkatnyaintelektualitas Islam merupakan gejala baru, seperti orang yang baru masuk Islam. 